\title{
Euroscepticism and Opposition to British Entry into the EEC, 1955-75
}

Euroscepticisme et opposition à l'adhésion britannique au Marché Commun, 1955-1975

Richard Davis

\section{OpenEdition}

\section{Journals}

Electronic version

URL: https://journals.openedition.org/rfcb/1364

DOI: $10.4000 /$ rfcb.1364

ISSN: 2429-4373

Publisher

CRECIB - Centre de recherche et d'études en civilisation britannique

Electronic reference

Richard Davis, "Euroscepticism and Opposition to British Entry into the EEC, 1955-75", Revue Française de Civilisation Britannique [Online], XXII-2 | 2017, Online since 30 mai 2017, connection on 28 juin 2022. URL: http://journals.openedition.org/rfcb/1364 ; DOI: https://doi.org/10.4000/rfcb.1364

This text was automatically generated on 29 September 2020 .

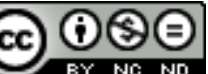

Revue française de civilisation britannique est mis à disposition selon les termes de la licence Creative Commons Attribution - Pas d'Utilisation Commerciale - Pas de Modification 4.0 International. 


\title{
Euroscepticism and Opposition to British Entry into the EEC, 1955-75
}

\author{
Euroscepticisme et opposition à l'adhésion britannique au Marché Commun, \\ 1955-1975
}

Richard Davis

\section{Introduction}

1 The 2016 debate leading up to the referendum in which the British people were asked to decide on their country's future inside or outside the EU revolved around a series of issues many, if not most, of which had been the subject of heated discussion for the previous fifty years. Nor was the 2016 referendum the first of its kind as much the same questions had been asked of a previous generation some forty years earlier. It seems unlikely that the vote in favour of leaving the EU, however clear this appeared to be, will close the debate. As events since June 2016 have shown, there remains a great deal of uncertainty as to what the future holds for Britain and for its relationship with the rest of Europe and with the EU as an institution.

2 The strength of Eurosceptical opposition to the European project, and to Britain's participation in it, has varied considerably over the course of the past fifty years, although more recently its importance has undoubtedly grown as has its ability to influence, decisively in June 2016, the political debate and decision makers. Rather than trace the growth of this movement and its political impact the present article will seek to consider the fundamental arguments on which this Euroscepticism, in all its different forms, has been based. The underlying theme, therefore, is to see how present-day antiEuropean sentiment, as expressed via UKIP, parts of the Conservative party or from a leftwing perspective, can be traced back to the earliest years of European construction. It will seek to show that many of the arguments used by the "leave" campaigners, and many of the deep-rooted Europhobe sentiments underlying them, are similar to those used in previous years. In this way the 2016 referendum can be seen as the latest example of a 
long-standing and persistent British Euroscepticism which needs to be traced back to the immediate post-war years and whose roots are to be found across the political spectrum and not solely in the Conservative Party at the time of the Maastricht Treaty.

\section{Euroscepticism: Some Origins and Definitions}

3 If the ideas that lie behind Euroscepticism are far older, the use of the term itself cannot be traced back beyond the mid-1980s and is nowhere to be found in the post-war debate on Britain's relations with the rest of Europe. From the Treaty of Rome up to and including the 1975 referendum, the term 'anti-Marketeer' was the most widely found, although this was not always used precisely. Indeed, the expression 'Common Market' was in itself something of a misnomer. Equally, both 'Euroscepticism' and 'antiMarketeer' have been the subject of varying interpretations and usages, especially in the popular media. ${ }^{2}$ Similar questions of definition also need to be asked about the exact meaning of 'Europe'. Precisely which of the many versions of 'Europe' is being opposed and criticised? This lack of a clearly defined idea of what Europe is or should be, and therefore of what Euroscepticism is, was evident from the outset of the debate on Britain's relations with the emerging European institutions after 1945. Europe has rarely been condemned in all its meanings, in a simply Europhobic sense. Instead, more often than not, it is 'the wrong sort of Europe' that is being attacked. Europe has taken on different meanings. Equally, the European institutions have never stood still and European integration or construction needs to be seen as an ongoing process that can take different directions. The Europe of the EU today, in many ways, bears little resemblance to the Europe of the European Coal and Steel and Community (ECSC) first put forward in 1950; nor does the Europe of the Euro Zone and the Schengen Area compare to De Gaulle's vision of a Europe des patries or to that proposed by Britain in the late 1950s in its Free Trade Area (FTA) scheme.

Defining the historical expressions of British Euroscepticism, and seeking to understand its origins and ideological bases, is not, therefore, easy. Tony Benn, one of the leading anti-marketeers of his generation, was keen to emphasise what he saw as the important distinction between the opponents of the EEC and anti-Europeans. "I was born a European and I will die one", he argued. But, he went on, "I have never put my alliance behind the treaty of Rome. I object to it. I hate being called an anti-European. How can one be anti-European when one is born in Europe?... What a lot of nonsense it is." ${ }^{3}$ Enoch Powell made much the same argument regarding his own position. While it has often been possible to portray some Eurosceptics as 'Little Englanders' and xenophobes, others have been critical of the various European bodies on the ground that they are insufficiently international, that they have sought to adopt a narrowly European perspective as opposed to a truly global one.

\section{Britain, Europe and the World: Distance, Exceptionalism, Superiority?}

When considering the opposition of many people in Britain to Europe and to European integration after 1945 it is commonplace to point to various fundamental differences that have reinforced the sense of separation between Britain and its continental neighbours. 
Just how far British 'exceptionalism' is a reality is debatable. Indeed, 'is Britain European?' is perhaps the most fundamental question, one that has been at the heart of the debate around Britain's relations with the rest of Europe for the past half century. For numerous Eurosceptics the answer has either been 'no', or at least not European in the sense of the EEC-EU.

6 Numerous accounts have traced the origins of Britain's distanced attitude towards the rest of the continent back to the Roman Empire, the Hundred Years' War, to the Reformation and Henry VIII's break with Rome, and the 'Glorious Revolution'. In this vision Britain's adoption of a constitutional monarchy set it in opposition to the absolutist regimes elsewhere in Europe. In some ways the very creation of the British state left behind a legacy of Euroscepticism. English, and then British, nationalism, like all other forms of nationalism, was necessarily based on a sense of difference and of separation from an 'Other', from other neighbouring, and often rival, nationalisms. For most of English or British history this 'Other' could only have been European. This sense of differentiation was reinforced by the long record of Britain's opposition to continental tyranny in the form of Philip II, Louis XIV, Napoleon or the Kaiser. However doubtful such an interpretation of Britain's past relations with the rest of Europe may be today, for past generations, up to and including those of the 1940s and 1950s, this image of British liberties being defended against the threat from the Continent was deeply rooted at all levels of British society. These accounts were part of a broadly Whig interpretation of British history that can be taken back to Thomas Babington Macaulay in the 1840s and which continued to exercise a significant influence, as did the later similar popular histories of such historians as H.A.L Fisher ${ }^{4}$ and G. M. Trevelyan ${ }^{5}$, in the 1920 s and 1930 s. For the generation of post-war leaders, and for the country as a whole, the more immediate memories of British resistance against the threats of Fascism and Nazism significantly reinforced this sense of mistrust of Continental Europe.

7 Another aspect of Britain's apparent exceptionalism that has often been pointed to is the British sense of pragmatism and empiricism and the contrast with the more ideological and theoretical approach of many on the Continent. The distinction between the generally uncodified British common law, and Britain's unwritten constitution, and the continental tradition of civil law has also been looked to as an explanation of this AngloContinental divide. ${ }^{6}$ The presentation of the European project in the 1950s, and later, in such theoretical and legalistic terms reinforced the reluctance of most British people to be part of them. Britain's first post-war Foreign Secretary, Ernest Bevin, explained Britain's refusal to be part of the ECSC by arguing that "Once you open that Pandora's box all sorts of Trojan Horses will fly out." "What for him appeared to be the abstract and unrealistic thinking behind the project had little appeal. Many other Britons took a similar view. Enoch Powell similarly pointed to the fact that four of the six initial member states of the EEC were recent creations in European history and that all of them had recently created constitutions and assemblies which, he argued, made them more amenable to the creation of another new, European, political structure.

8 Many observers of Britain's relations with Europe, on both sides of the Channel, have often pointed to the fundamental fact that Britain is an island in order to get to what they see as the roots of this divide. De Gaulle's veto of the first British application to enter the EEC in January 1963 was in large part justified by repeated references to Britain's insular and maritime status. Britain, he said, was simply not European enough and had "in all her doings very marked and very original habits and traditions. In short, the nature, the structure, the 
very situation that are England's differ profoundly from those of the continentals." ${ }^{.8}$ There were many on the other side of the Channel who agreed with his analysis. In 1951 the Labour Party pamphlet 'European Unity' had argued that "in every respect except distance, we in Britain are closer to our kinsmen in Australia and New Zealand on the far side of the world, than we are to Europe". ${ }^{9}$ For Enoch Powell the physical Anglo-Continental divide had lost none of its significance for Britain's national identity even in the nuclear age.

That Britain is linked not only to the rest of Europe, which even the most strident of Europhobes have had to recognise, however reluctantly, but also to the wider world is another factor that has been emphasised by observers and historians of the AngloContinental relationship. Churchill's 1948 'three circles' theory retained its relevance for all British leaders throughout the 1940s, 50s and 60s. While they recognised that Britain could not afford to cut itself off from Europe none of them were prepared in any way to give up Britain's world role or to see Britain as anything other than a global, and not just a regional, player. All this inevitably fed into a distanced attitude towards Europe and the British sense of superiority over the continental Europeans. In turn this was a central aspect of the country's Euroscepticism.

Anti-European attitudes, the denigration of old enemies and even of present-day allies, and a simple lack of belief in the European projects, contrasted sharply with the general British attitudes towards the rest of the world, at least towards the English-speaking world in the Commonwealth and the United States. For many in Britain the idea that these parts of the world were populated by their 'kith and kin' was still strongly felt especially when compared to the essentially foreign continentals. Many Britons felt far more at home in their dealings with those parts of the world they knew best, the old Dominions and the United States, than with Europe. One opinion poll showed in 1966 that when asked to rate the countries they most trusted, Australia came out on top, followed by Sweden, the United States and India with Germany and France only fractionally above the USSR. ${ }^{10}$ For so long as this belief that Britain was more naturally part of Churchill's 'English-speaking world' than it was of Europe, and for so long as the country's decisionmakers felt that they had more attractive alternatives beyond Europe which could best meet their needs, whether they were economic, commercial, cultural, political, strategic or in any other field, then they were unlikely to view favourably the moves to construct a new united and integrated Europe. Without ever being anti-European, or Europhobe, these hard-headed, but ultimately short-sighted, calculations of British interests encouraged British hesitations with regard to Europe and reinforced its underlying sense of Euroscepticism.

11 Such sentiments had long been present in much of British thinking. It was, however, the experience of the Second World War that had the greatest impact on British thinking towards Europe after 1945. In many ways it continues to play a significant part in the same debate today. For the British, the story of the War, which the British people have been constantly reminded of ever since by the media and in their popular culture, especially on TV and in film, was one of heroic resistance and final victory. Where the continental Europeans had collapsed, Britain survived intact. In this vision, Britain was neither guilty of having turned to Fascism or Nazism, and thereafter of unleashing the war, nor of the atrocities that accompanied it. Its history was fundamentally different from that of its initial allies who, through their weakness, had collapsed in the face of this challenge. Britain was neither an aggressor nor a collaborator. Whereas the countries on the continent had failed in one way or another, Britain had simply won. For many on the 
Continent, therefore, it was far easier to accept that the nation state as a model for arranging international affairs had failed and that a new system was required. Britain, which had not suffered such a shock to its system was, as yet, unwilling to undertake such a fundamental rethinking. It remained very much wedded to its existing political order and to the idea, however illusory this was becoming, of its status as a global power. This later aspect of its self-portrayal was, seemingly, supported by the fact that it remained at the head of the Empire-Commonwealth and by the 'special' relationship it enjoyed with the United States.

Suspicions of Germany remained strong and when, by the late 1950s, West Germany appeared to be not only challenging Britain but surpassing it in many areas, these feelings were only intensified. In 1958, the Prime Minister, Harold Macmillan, warned that "Western Europe dominated in fact by Germany and used as an instrument for the revival of power through economic means... is really giving them on a plate what we fought two wars to prevent." 11 One British official similarly warned that the EEC would provide "a means of reestablishing the hegemony of Germany". ${ }^{12}$ Other anti-German sentiments were of a more xenophobic nature. In 1960 one Labour MP expressed his disagreement with those of his colleagues "who feel that Germany is our normal ally and that there is no anti-German prejudice", added that "If there is not there ought to be." ${ }^{13}$ The denigration of other Europeans, especially of the French during the years of the Fourth Republic, was equally commonplace. As late as the 1960s, Clement Attlee told one newspaper "I'm not very keen on the Common Market. After all, we beat Germany and we beat Italy and we saved France and Belgium and Holland. I never see why we should go crawling to them". ${ }^{14}$ Speaking in the late 1960 s he repeated the same message: "We are asked to join the Six. The Six", he repeated before concluding in typically laconic fashion: "I seem to remember that we spent a lot of blood and treasure during the War rescuing four of them from the other two." 15

\section{Opposition to the nascent European project in the 1950s}

The decision to stand aloof from the moves towards an integrated western European structure in the 1950s, a decision taken by successive British governments and supported by an overwhelming majority of the population, was based on a combination of all the long-established factors given above. This conclusion was reached almost automatically with little or no discussion. Throwing in Britain's lot with the rest of Western Europe hardly seemed an attractive prospect. Nor did it seem to offer the possibility of meeting the country's needs. In particular, trade with the countries of the Commonwealth still seemed to offer the best prospects, although recent evolutions were beginning to undermine this assumption. Perhaps most importantly, attitudes towards Europe, both in official circles and in the country as a whole, were still heavily tainted by the recent experiences of war. They stood in stark contrast to the still largely positive vision held of the Commonwealth and of Britain's global role.

Attlee explained his government's rejection of the invitation to take part in the ECSC project when he told the Commons that they were "not prepared to accept the principle that the most vital economic forces of the country should be handed over to an Authority that is utterly undemocratic and is responsible to nobody." 16 This was reinforced by the fear that the new Europe that was emerging on the Continent would become protectionist. Although 
Britain's own free trade and laissez-faire credentials were far removed from those of the classical economic liberals of the nineteenth century, differences of approach with Britain's continental neighbours could still be seen. Where the 'Six' were moving towards a regional, European, customs union, based on a system of regulated trade, exemplified by the Common Agricultural Policy, with a degree of protectionism in the form of a common external tariff, Britain's preference was always for a more global, multilateral and free market approach. The preferred model in London was that of the OEEC and later the OECD. Britain's FTA proposal in the late 1950s as an alternative to the EEC stood in stark contrast to the emerging EEC model. The rejection of the FTA by the Six marked a first, and important, reversal for the British and their attempts to achieve the 'right sort of Europe'.

These divergences between Britain and the Six were visible across both major political parties in Britain. The Labour Party's traditions and culture made its opposition to the project to create an integrated and supranational Europe almost inevitable. The origins of the Labour Party were in many ways quite distinct from those of its sister parties on the Continent. Its attachment to the Commonwealth was strong and the belief that this new Europe was being driven by right-wing Christian Democratic parties on the Continent and that it was, at heart, a capitalist, and perhaps a Catholic, club only served to reinforce the deeply felt scepticism among most, but not all, Labour leaders and their supporters. Although it was under his premiership that the first EEC application was made Macmillan initially saw the EEC as a serious threat to Britain, potentially as a renewed form of Napoleon's continental blockade. This, he warned, might start an economic and commercial war that could become even more serious if left unchecked. This opposition to the sort of protectionist, and potentially anti-American Europe, envisaged by De Gaulle was to become a source of serious concern for the British over the next decade.

\section{Opposition to the three EEC applications}

In the 1950s the idea of Britain joining with the Six as part of the ECSC or the EEC was unthinkable to the vast majority of the political establishment and to the country as a whole. The rapidly changing international context, and the increasing doubts as to Britain's domestic situation, which brought about a rethinking of this previously distanced attitude towards European integration and which led, in 1961, to the decision to open talks with the Six on terms for British membership of the EEC, shattered this comfortable consensus. With the prospect of Britain now actually joining with the other Europeans in a united Europe the opposition to this move now came to the fore. It was also at this time that Europe became a dominant issue between and within the political parties. At the meeting of Commonwealth Heads of government in September 1962 Gaitskell was making noises to the effect that should they oppose the terms agreed to by the Conservative government and the Six then they could count on the support of Labour. Wilson later argued that "If there has to be a choice, we are not entitled to sell our friends and kinsmen down the river for a problematical and marginal advantage in selling washing machines in Dusseldorf." ${ }^{17}$. It was, however, Gaitskell's speech to the Labour Party Conference in October 1962 that was the clearest expression of Labour opposition to EEC membership. This is rightly remembered as one of the most fundamental presentations of the Eurosceptical case which raised fundamental points that "have resonated throughout the European debate" ${ }^{18}$ For Martin Holmes it was a "seminal critique". ${ }^{19}$ In this speech Gaitskell 
pulled together a range of different arguments against Britain's entry to the EEC, many of which have been central to the debate ever since and which are still in varying forms at the heart of the present-day debate.

His first points took the form of a concrete appraisal of the advantages and disadvantages for Britain of being inside or outside the EEC and argued that the Commonwealth remained essential for Britain's trade. In particular, he pointed to the danger of food prices rising in the event of Britain entering the EEC. Much was made of this last argument in the anti-EEC campaigns throughout the 60s and 70s. The key Eurosceptic points, however, were not based on economics. Gaitskell, in fact, accepted that the balance between loss and gain following a British entry to the EEC was unsure. The main thrust of his argument was political and it is this part of his speech that we find the essentially Eurosceptic case against British membership of the EEC and where his dire warnings for the future were most visible. He recognised that Europe "had a great and glorious civilisation" and could "claim Goethe and Leonardo, Voltaire and Picasso" but, he continued, "there have been evil features in European history, too - Hitler and Mussolini... You cannot say what this Europe will be: it has its two faces and we do not know as yet which is the one which will be dominant." The future development of Europe was, therefore, uncertain; Europe and the Europeans could still turn one way or another.

If the future moral character of Europe was still in doubt, Gaitskell was equally wary of the EEC's political ambitions to move towards a "political union", going beyond a "customs union" by "stepping towards political integration" in a "political federation". Gaitskell also skilfully played on the fears both in his Party and in the country at large when he emphasised, firstly, the uncertainty about what Britain was potentially signing up to should it enter the EEC and, secondly, the need to be sure about this before Britain committed itself. His key argument turned to the central issue of the loss of sovereignty in an integrated Europe. Political federation, he warned, was the clear objective of those who had created the EEC. In particular, his answer to his rhetorical question "What does federation mean?" revealed the depth of his opposition to the whole idea:

It means that powers are taken from national governments and handed over to federal governments and to federal parliaments. It means - I repeat it - that if we go into this we are no more than a state (as it were) in the United States of Europe, such as Texas and California... This is what it means; it does mean the end of Britain as an independent nation state... the end of Britain as an independent European state... the end of a thousand years of history... And it does mean the end of the Commonwealth. How can one really seriously suppose that if the mother country, the centre of the Commonwealth, is a province of Europe (which is what federation means) it could continue to exist as the mother country of a series of independent nations? It is sheer nonsense. ${ }^{20}$

Gaitskell may not have entirely ruled out the idea of Britain entering the EEC should the right terms be met: maintaining Britain's position and advantages in the Commonwealth, safeguarding the interests of the countries of the recently formed European Free Trade Association, Britain's right to plan its economy, the maintenance of the system of support for British farmers and an independent foreign policy, and the refusal to contemplate a supranational system or to sign up to a commitment to an 'ever closer union'. However, there was little doubt of the Euroscepticism of his message. Beyond these conditions Gaitskell also pointed to the negative impact of EEC policies on the countries of the Commonwealth. Already the accusations that the Conservative government was selling short both Britain and its old friends in the Commonwealth, and that its assurances, 
promises and pledges could not be trusted, was central to his case. This tendency to use the European debate to score points over their political adversaries was to be a characteristic of the Labour Party's attitude over the next fifteen years.

Gaitskell also raised another issue that was to become central to the whole Eurosceptic case in later years: that of popular sovereignty and the ultimate power of the people to take the final decision on British entry to the EEC. Recalling the decision of Stanley Baldwin to go to the country over the question of tariff reform in 1923, he warned against the idea that the government alone was best placed to decide. Even though Macmillan had not clarified this point, and it remained clear that Parliament would have to give the final approval for any British entry to the EEC, Gaitskell rounded on the Conservatives:

We are now being told that the British people are not capable of judging this issue the Government know best; the top people are the only people who can understand it; it is too difficult for the rest. This is the classic argument of every tyranny in history... We did not win the political battles of the 19th and 20th centuries to have this reactionary nonsense thrust upon us again.

... 'We must go in,' they say, 'not because the power of logic, of fact and conclusion suggest that it is to our advantage; we must go in because the people who really understand it, the top people, all want it.'... But what an odious piece of hypocritical, supercilious, arrogant rubbish is this!... It is all on a par with the argument of inevitability. 'You cannot escape: you must be with it. You must belong, no matter to what you belong.' What a pitiful level of argument we have reached! ${ }^{21}$

21 Gaitskell's conclusion, without coming down definitively against British membership, left little doubt of his strong Eurosceptic principles. His patriotic call to refuse British entry, unless the right terms were won from the Six, was that in this case "then we must stand firm by what we believe, for the sake of Britain, and the Commonwealth and the World; and we shall not flinch from our duty if that moment comes." 22

After Gaitskell's untimely death a few weeks after this speech, his views were carried on by various Labour campaigning groups such as the 'Forward Britain Movement', the 'Britain and the Common Market Group', and the 'Labour Committee for the Five Safeguards on the Common Market'. Their supporters included Douglas Jay, Barbara Castle, Emmanuel Shinwell, Richard Crossman, Peter Shore, Denis Healey and Tony Crosland. In 1965, the then Labour Prime Minister, Harold Wilson, and his Foreign Secretary, Michael Stewart, warned against the way the new Europe was developing. The danger, as they saw it, was that Europe would evolve into a 'closed shop', all the more worrying as this would be under the leadership of General De Gaulle. Furthermore, what Wilson termed the "right sort of Europe" had to be "genuinely outward looking, and not autarkic". If not then it would be "inimical to Atlantic, and more particularly, Commonwealth links ". As so often throughout the course of the troubled relationship between Britain and the EEC-EU the question of agriculture and the CAP, and behind this the more fundamental question of how the EEC-EU was to be financed and Britain's contribution to this, was the "real test" for Wilson. ${ }^{23}$ In one interview with the French leader, Wilson went so far as to recognise that the EEC, as it then stood, was hardly compatible with the Commonwealth, the two institutions being fundamentally incompatible, in particular in terms of their respective trade policies. Paradoxically it was Wilson who launched the second, unsuccessful, application to enter the EEC only two years later.

While Wilson and Stewart were not outright Eurosceptics their support for British entry to the EEC was at best conditional and tainted by a large degree of suspicion and doubt 
about the whole European project and, equally significantly, about Britain's compatibility with it. As Wilson admitted, he had "never been emotionally a Europe man." ${ }^{24}$ One of his personal advisors thought he was "basically a north of England, non-conformist puritan... The continental Europeans, especially from France and southern Europe were to him alien. He disliked their rich food, genuinely preferring meat and two veg with HP sauce." ${ }^{25}$ There were many others in the Labour Party who, like Tony Benn, "loathe(d) the Common Market", condemning it unreservedly as "bureaucratic and centralised" 26 , as a body where the unelected officials called the shots. The left remained fundamentally opposed to the EEC on the grounds of the loss of sovereignty that membership would involve. If Britain was inside the EEC, they argued, it would be unable to follow the socialist programme, embodied in the alternative economic strategy, it was supporting at home, particularly planning and state intervention in the management of the economy and trade protectionism.

There was also a degree of internal division in Conservative ranks. Macmillan recognised that "it was... asking a great deal of the Conservative Party, so long and so intimately linked with the ideal of Empire, to accept the changed situation". Following the opening of negotiations with the Six in 1961 he recorded his concerns in his diary. "There are", he wrote, "many very anxious Conservatives. It is getting terribly like 1846" when the Conservative Party was split for a generation following the repeal of the Corn Laws. His fears extended to the possible reactions of the British people to his European initiative given their "instinctive anxiety and even suspicion... about the ambitious plan which the Government was now anxious to promote" and their "long tradition of isolation (and) a certain suspicion of foreigners." 27 Numerous leading Conservative Eurosceptics such as R.A. Butler, Max Aitken, Harry Legge-Bourke and Peter Walker continued to express their reticence, and sometimes outright opposition, to the EEC. The most outspoken Conservative Eurosceptic voice was that of Enoch Powell who challenged his Party leader, Edward Heath, head on over the question of Europe from the late sixties onwards. At the 1971 Party Conference, he made a passionate plea against British entry into the EEC and the loss of sovereignty that this would entail. However, the Conference voted by 2,474 votes to 324 in favour of British entry.

\section{The campaign against EEC membership and the 1975 referendum}

By the time the third, successful, application was launched in 1971 the opposition to British membership of the EEC had become far more organised in both the Labour and the Conservative Parties. The difficult passage through Parliament of the required legislation was evidence of the growing strength and widening support for anti-EEC groups. This was already evident in the Conservative Party ranks during the 1970 election campaign. Most Conservative candidates chose to avoid mentioning the issue in their campaigns although it has been estimated that around $10 \%$ came out against or expressed major reservations. In the newly elected Parliament around sixty Conservative MPs could be identified, in varying degrees, with this group although not all were prepared to openly confront the Party leadership on this issue. Most significantly, the number of Conservative antiMarketeers was higher than the government's overall majority thus giving them a potential influence beyond their numerical strength. The final outcome would, therefore, depend on the government winning the support of at least a minority of Opposition MPs. 
The vote on the principle of British membership of the EEC in the House of Commons in October 1971 was carried comfortably but 39 Conservatives voted against the government's line and two others abstained. This was more than compensated for by the sixty-nine Labour MPs who voted in favour. Later votes were, however, far closer, sometimes being won by fewer than ten votes. This was the first sign of what was later to become an open breach in the Conservative Party. Importantly, the Conservative antiMarketeers were becoming an organised and clearly identifiable group that was able and willing to challenge Party unity on what they regarded as an issue that went beyond Party discipline and unity. Although they were unable to block British entry the Eurosceptics had already seriously undermined the bases on which British membership depended. Britain's entry to the EEC on the third attempt in 1973 in no way meant the end to the Eurosceptics' campaign.

After only two years as a member of the EEC it was, of course, too soon, in 1975, to take stock of the benefits of Britain's new position in Europe. There were, however, many opponents of the EEC who argued that since Britain had 'joined Europe' the country's economic troubles had only increased. From there to arguing that this was the fault of Europe was an easy step. Adjustment to the EEC was always going to be difficult and the economic competition, especially from West Germany, was, as expected, severe. For many this compared unfavourably with the economic relations Britain had enjoyed with the Commonwealth. These arguments were reinforced by the fact that at the very moment that Britain entered the EEC the world economy was thrown into recession. Coming on top of the breakdown of the post-war international financial and monetary order, this resulted in unprecedented levels of inflation and a sharp drop in economic growth.

The deep divisions within the Labour Party over Europe at the time of the first British applications to enter the EEC in the 1960s were as nothing to those that emerged in the following decade. Perhaps more than any other issue that of Europe came to be a decisive dividing line within Labour ranks. The defeat in the 1970 election, as is so often the case, led to renewed calls from many within the Labour Party that their whole approach be reappraised. Frustration and disappointment among many Party members that the Labour governments of 1964-70 had failed to implement the socialist programme that they had been elected on produced renewed calls for a more genuinely socialist approach should Labour be returned to office. This approach was hardly compatible with membership of the EEC. Moreover, the Labour left seized on the question of Europe and of British membership of the EEC as a stick with which to beat the Party leadership and which, they hoped, could serve to unite a majority of the Party behind a series of policies that were both anti-British membership of the EEC and resolutely socialist. In this way Europe, and the left's staunch anti-EEC position, became the key issue in the battleground between the rival Labour factions. Social democrats in the Party such as Roy Jenkins, who for the most part were in favour of British membership, became the number one targets for the left's attacks. In this way the left's Euroscepticism was directed not only against the Conservative government's application in 1971-73 but also against those in their own Party who supported this approach. Europe was, therefore, a political football not only between the two parties but, equally importantly, in the ideological battle for dominance inside the Labour Party.

The Conservatives, who have since the late 1970s become the leading exponents of the Eurosceptic, anti-EEC-EU, message, were up until the mid to late 1970s rightly regarded as the more pro-European of the two major political parties. So long as the EEC was regarded 
in essentially economic and commercial terms, as above all a trading area, then the vast majority of Conservatives found little to object to in the EEC. The Conservatives under Macmillan and Heath had been the driving forces behind the redirection of British policy towards a more pro-European stance. Unlike the Labour Party, they had not overtly sought to make political capital out of their opponents' European policies and they had broadly supported Wilson's 1967 EEC application. This should not be taken to mean, however, that the Conservative Party in the 60s and 70s was without any trace of Euroscepticism. Firstly, the first EEC application can hardly be seen as proof of a fundamental Euro-enthusiasm. It was characterised rather by its hesitancy and its halfhearted nature. Macmillan's application, as many contemporary observers noted, was at best lukewarm. Nor was it in reality a straightforward request to enter the EEC but rather an opening of talks with the other Europeans to see if the conditions existed that would allow Britain to effectively enter the EEC. The negotiations, once they were underway, soon showed the extremely qualified nature of the British negotiating position. The scepticism of many in Britain, including many of those in favour of British entry, was clear to see. Moreover, the argument that Britain was seeking to enter the EEC in order to redirect it along quite different lines from those being set out by the 'Six' is one that has, understandably, been given a good deal of credit.

That Britain was seeking to play the role of the Trojan Horse, attempting to enter the EEC to destroy it from within - or at least to transform it - or that it was trying to nip European construction in the bud, remains convincing. Macmillan, for example, told the Cabinet in 1961 that the creation of the EEC was "a threat to the political position of the United Kingdom as a world Power" and that it would be "consistent with our traditional policy to seek to prevent the concentration of undue strength in a single political unit on the continent of Europe." ${ }^{28}$ As such it remains hard to see Macmillan and other apparently pro-European voices in any other light than a Eurosceptic one. As is so often the case in the European debate this comes back to what precisely we mean by 'Europe'. What is clear is that the vision held by those in Britain seeking to enter the EEC was often quite different from the prevailing view within the greater part of the continental elites.

30 Evidence of Euroscepticism was found across the United Kingdom although in a significantly different manner from the situation in 2016. Whereas today the EU is seen by most SNP and Plaid Cymru supporters as an opportunity to promote their causes in the 1970s this was far from being the case. Instead the EEC was presented as inimical to selfgovernment, dangerous to the particular economic interests of Scotland and Wales in areas such as agriculture and fishing and as undemocratic and centralised. Opposition to the EEC was stronger in Scotland than elsewhere in the UK and one poll in 1971 suggested that $81 \%$ of Scots were opposed to EEC membership. The official SNP line reflected this Eurosceptic mood in the country and it openly condemned the 'English Parties', Labour and the Conservatives, for seeking to force the Scots into a European grouping against their will. In the 1975 referendum the 'No' vote for the UK as a whole was $32.8 \%$. In England it was $31.3 \%$ and in Scotland $41.6 \%$.

31 The campaign leading up to the 1975 referendum brought together a wide-ranging collection of Eurosceptic voices in the cross-party National Referendum Campaign. Its founding members were Douglas Jay and the Conservatives Neil Marten and Richard Body. It also drew on support from the SNP and Plaid Cymru, the Ulster Unionists and from a small number of free trade Liberals. Overall its support came from the left-wing of the Labour Party and the right wing of the Conservatives. Leading Labour figures who 
gave their support included Tony Benn, Peter Shore, Barbara Castle and Michael Foot. The trade union leaders Hugh Scanlon and Jack Jones joined them. Bringing together such diverse leaders as Tony Benn and Enoch Powell was never going to be easy. The group was marked by its lack of overall unity and often campaigned from quite different, and sometimes mutually contradictory, angles. Its ultimate failure was beyond doubt. The vote in the House of Commons on the renegotiated terms in April 1975 was unambiguous with 398 voting in favour and 172 against. Only eight Conservatives voted against with eighteen others abstaining. The vast majority of opponents were found among the ranks of the Labour MPs with 145 voting against. The referendum vote was equally clear-cut with a two-thirds majority voting in favour.

\section{Conclusion}

Looking at the record of early British Euroscepticism it is easy to identify certain themes that have been at the heart of the campaign to see Britain adopt a more distanced position from Europe and from its integrated political institutions. For the more radical Eurosceptics, and for out and out Europhobes, this became not just a question of distancing Britain from the Continent but of breaking away from it or, as they saw it, of breaking free. Although they failed in the 1975 referendum, one of the significant successes of those who supported the Eurosceptic cause from the 1960s onwards was their ability to increasingly set the agenda and fix the terms of the European debate in Britain as a whole. This was reinforced by the tendency, especially visible in the approach of the Labour Party leadership in the 1950s, 60s and 70s, to use the European question as a political football, as a means of scoring short-term electoral points at the expense of their political opponents.

Scepticism towards Europe and the various institutions that have, since the end of the Second World War, constituted the increasingly integrated Europe as it exists today, has taken numerous different forms and its impact on British policy has varied over time. The depth of Eurosceptic sentiment depends very much on what Europe we are addressing. Nor is Europe, and its institutions, fixed but rather a constantly evolving idea and set of structures and organisations. Euroscepticism also came from different ideological starting points and focused on differing elements of what, taken together, make up Europe. It also ranged in intensity, from a mild form of pragmatic doubt or lack of faith in the European ideal and in the various ways this was being put into effect, to the unwavering and essential opposition coming from figures such as Enoch Powell and Tony Benn. Across the wide spectrum of Eurosceptic groups, Europe has been presented as a problem to be solved rather than as an opportunity to be seized; as at best an unwelcome development that they would have liked to see go away and at worst as a challenge to be resisted, often in Saint George like mode; the EEC/EU regarded as the latest in a long list of threats that Britain has had to face over the course of its history. As Anthony Forster has argued, "the Euroscepticism which emerged following the Bruges speech has a long lineage...". ${ }^{29}$ and many of the concerns and arguments presented by the recent 'Leave' campaign need to be traced back several decades.

Richard Davis is Professor of British Civilisation at the University of BordeauxMontaigne where he teaches contemporary British history and politics. He holds a BSc(Econ.) from the London School of Economics in international relations, a PhD from the University of Sheffield in international history and agrégation in English. 
His is the author of several books and articles on British foreign policy in the twentieth century. His latest work is Britain in Crisis (1970-1979) published by the Presses Universitaires de France in 2016.

\section{BIBLIOGRAPHY}

Benn, Tony, Conflicts of Interest. Diaries 1977-80 (London, Hutchinson, 1990).

Black, Jeremy, Convergence or Divergence? Britain and the Continent (London, Palgrave, 1994).

Bogdanor, Vernon, 'Learning from History? The 1975 Referendum on Europe', Gresham College Lecture, 23 May 2016 (http://www.gresham.ac.uk/lectures-and-events/learning-from-historythe-1975-referendum-on-europe).

Forster, Anthony, Euroscepticism in Contemporary British Politics. Opposition to Europe in the British Conservative and Labour Parties Since 1945 (London and New York, Routledge, 2002).

Griffiths, Richard T. and Ward, Stuart, Courting the Common Market. The First Attempt to Enlarge the European Community 1961-1963 (London, Lothian Foundation Press, 1996).

Hennessy, Peter, The Prime Minister. The Office and its Holders Since 1945 (London, Penguin, 2001).

Holmes, Martin (ed.), The Eurosceptical Reader (Basingstoke, Palgrave-Macmillan, 1996).

Lieber, Robert J., British Politics and European Unity: Parties, Elites and Pressure Groups (Berkeley, California University Press, 1970).

Macmillan, Harold, At the End of the Day, 1961-1963 (London, Macmillan, 1973).

Simms, Brendan, Britain's Europe. A Thousand Years of Conflict and Cooperation (London, Allen Lane, 2016).

Young, Hugo, This Blessed Plot (London, Macmillan, 1998).

\section{NOTES}

1. See Anthony Forster, Euroscepticism in Contemporary British Politics. Opposition to Europe in the British Conservative and Labour Parties Since 1945 (London, 2002), p. 2.

2. See Ibid., 'Chapter 1: Defining and explaining Euroscepticism'.

3. Tony Benn to the House of Commons, 20 November 1991, Hansard, Column 335 (http:// www.publications.parliament.uk/pa/cm199192/cmhansrd/1991-11-20/Debate-6.html).

4. H.A.L. Fisher, History of Europe (London, 1935).

5. G.M. Trevelyan, History of England (London, 1926).

6. See Linda Colley, Acts of Union and Disunion (London, 2014), Chapter 14 'Constitutions'.

7. Vernon Bogdanor, Gresham College Lecture, 'Learning from History? The 1975 Referendum on Europe', 23 May 2016 (http://www.gresham.ac.uk/lectures-and-events/learning-from-historythe-1975-referendum-on-europe).

8. Kessing's Contemporary Archives, Vol. 14 (1963-64) p. 19197.

9. Brendan Simms, Britain's Europe (London, 2016) p. 179. 
10. Survey conducted for New Society quoted in Robert J. Lieber, British Politics and European Unity: Parties, Elites and Pressure Groups (Berkeley, 1970) p. 259.

11. Brendan Simms, Britain's Europe, p. 170.

12. Ibid., p. 181.

13. Anthony Forster, Euroscepticism, pp. 13-14.

14. Edward Heath, The Course of My Life (London, 1988) p. 355.

15. Vernon Bogdanor, 'The 1975 Referendum'.

16. Jeremy Black, Convergence or Divergence? Britain and the Continent (London, 1994) p. 236.

17. Hugo Young, This Blessed Plot (London, 1998) p. 157.

18. Vernon Bogdanor, 'The 1975 Referendum'.

19. Martin Holmes (ed.), The Eurosceptical Reader (Basingstoke, 1996), p. 1.

20. Ibid, pp. 13-37.

21. Ibid., pp. 13-37.

22. Ibid., pp. 13-37.

23. Public Record Office, PREM 13/306. Note by Michael Stewart for Harold Wilson, 3 March 1965.

24. Peter Hennessy, The Prime Minister. The Office and its Holders Since 1945 (London, 2001) p. 365.

25. Ibid., pp. 365-66.

26. Tony Benn, Conflicts of Interest. Diaries 1977-80 (London, 1990).

27. Harold Macmillan, At the End of the Day, 1961-1963 (London, 1973) p 5 and p. 19.

28. Richard T. Griffiths and Stuart Ward, Courting the Common Market. The First Attempt to Enlarge the European Community 1961-1963 (London, 1996) p. 7.

29. Anthony Forster, Euroscepticism, pp. 2-3.

\section{ABSTRACTS}

While British Euroscepticism is frequently regarded as a phenomenon of the 1980s and 1990s and is most often seen in relation to the Conservative Party and the Thatcher and Major governments, particularly in the years leading up to and immediately after the Maastricht Treaty, the key ideas that are associated with it could already be found in the debates around Britain's place in Europe in the previous decades.

From the earliest years of European integration with the ECSC in 1950 the refusal to be part of this process was almost unanimously supported in Britain. The multiple arguments behind this choice included many that would today be termed 'Eurosceptic'. In 1961, as a result of the change of direction announced by the Prime Minister, Harold Macmillan, and the opening of talks with the 'Six' about a possible British entry into the EEC, the European question assumed a central place in British political life. The 'anti-marketeers' mobilised support across the political spectrum, somewhat less among the ranks of the Conservatives, far more in the Labour Party.

From both the left (Tony Benn) and the right (Enoch Powell), and at times drawing on quite different arguments, the campaign against the EEC during the 1975 referendum was unable to win over a majority of public opinion. Nonetheless, the supporters of this first attempt at a "Brexit" did succeed in placing the European question, and that of Britain's place in Europe, at the centre of both the national political debate and of the ideological and political struggles that were tearing apart the Labour and Conservative Parties. The clashes between rival factions in the two parties in large part revolved around this question of Europe. One consequence of this was 
that the 'anti-marketeers' of these years established the ideological and organisational foundations for the following generation of Eurosceptics.

Si l'Euroscepticisme en Grande-Bretagne est d'habitude considéré comme un phénomène des années 1980 et 1990, et vu par rapport au parti conservateur et aux gouvernements de Margaret Thatcher et de John Major, surtout à l'époque du Traité de Maastricht, les idées qui y sont associées se trouvaient déjà dans les débats sur la place de la Grande-Bretagne en Europe dans les années 1950, 60 et 70 .

Au début de l'intégration européenne à partir de la création de la CECA en 1950, le refus d'y participer était quasi-unanime en Grande-Bretagne et cela pour de nombreuses raisons, y compris celles que nous appellerons aujourd'hui 'eurosceptiques'. En 1961, avec le changement de cap annoncé par le Premier ministre Harold Macmillan et la décision d'ouvrir les négociations avec les 'Six' sur une éventuelle adhésion de la Grande-Bretagne au Marché commun, la question européenne a assumé une place de première importance dans la vie politique britannique. La question brûlante de l'Europe a mobilisé les opposants à l'Europe de la C.E.E., les «antimarketeers ", qui trouvaient un soutien, dans une moindre mesure, chez certains Conservateurs et, surtout, dans le parti travailliste.

Venant de la gauche (Tony Benn) et de la droite (Enoch Powell), et avec parfois des arguments très différents, la campagne contre la C.E.E. lors du référendum de 1975 n'a pas réussi à réunir une majorité de l'opinion publique. Néanmoins, les partisans de cette première tentative d'un Brexit ont réussi à mettre la question de l'Europe, et de la place de la Grande-Bretagne en Europe, au centre du débat politique national et au cœur des combats idéologiques et politiques au sein $\mathrm{du}$ parti conservateur comme du parti travailliste. La lutte de pouvoir entre les différentes factions dans ces deux partis tournait en grande partie autour de cette question de l'Europe. En cela, les 'Anti-Marketeers' des années 1970 ont posé des bases organisationnelles et idéologiques pour les Eurosceptiques de la génération suivante.

\section{INDEX}

Keywords: Referendum, Euroscepticism, Europhobia, Conservative Party, Labour Party

Mots-clés: Référendum, Euroscepticisme, Europhobie, parti conservateur, parti travailliste

\section{AUTHOR}

\section{RICHARD DAVIS}

Université Bordeaux-Montaigne 